Richard Pfeilstetter

\title{
Mann der Tat, Enterprise Culture and Ethno-preneurs: Discussing the Scope of Affirmative, Critical and Pragmatic Approaches to Entrepreneurship in Spain
}

This is the pre-copyedited author's final version of the journal article accepted for publication following peer review.

Original citation:

Pfeilstetter, R. (2016). Mann der Tat, Enterprise Culture and Ethno-preneurs: Discussing the Scope of Affirmative, Critical and Pragmatic Approaches to Entrepreneurship in Spain. Sociologus, 66 (2), 183-202.

The version of record is available online at:

https://doi.org/10.3790/soc.66.2.183 


\section{Mann der Tat, Enterprise Culture and Ethno-preneurs:}

Discussing the Scope of Affirmative, Critical and Pragmatic Approaches to Entrepreneurship in Spain.

\section{Mann der Tat, Enterprise Culture und Ethno-preneurs:}

Eine Diskussion kritischer, affirmativer und pragmatischer EntrepreneurshipAnsätze am Beispiel Spaniens.

Richard Pfeilstetter*

This contribution suggests a classification of different anthropological contributions to entrepreneurship research. Critical approaches to entrepreneurship focus on the ideological bias of the term. As the work of Mary Douglas, they critique the methodological individualism and the utilitarian selfconcept underlying the entrepreneur. Affirmative approaches, in the tradition of Joseph Schumpeter or Frederik Barth, are concerned with the definition, understanding and transformative outcomes of entrepreneurship. Pragmatic approaches use tactically the social eminence of the term by expanding it to a wide range of apparently distant topics, such as the 'ethno-preneur' coined by John and Jean Comaroff. To illustrate the analytical scope of each of these approaches, I discuss some of my empirical material from Spain, such as the discourse on entrepreneurship in the 2015 parliamentary elections, the case of a media entrepreneur in rural Andalusia and the politics of heritage entrepreneurship and the Mediterranean diet in Catalonia.

Keywords: entrepreneurship; Spain; Andalusia; Catalonia; ethno-preneurship; Schumpeter

Schlüsselwörter: Gründertum; Spanien; Andalusien; Katalonien; ethnopreneurship; Schumpeter

Acknowledgements

This paper has been presented at the seminar series 'Dimensions of Agency' at the University of Leipzig. I am grateful to Katja Werthmann for the invitation and to all

\footnotetext{
* Lecturer at the Department of Social Anthropology, University of Seville (Spain), rgp@us.es
} 
the participants for their comments. Many thanks also to the anonymous reviewers from Sociologus and to the editor Eveline Dürr for the helpful observations.

\section{Introduction}

The seemingly ever-growing popularity of the concept of entrepreneurship contrasts with the comparatively limited attention it receives within anthropology (Swedberg 2000: 31). By way of explanation, it has been argued that anthropologists often opted for different concepts, such as 'traders', and tended to focus on group rather than individual economic action (Lindh de Monotoya 2000: 333, 334). Today, different disciplines are concerned with different aspects of entrepreneurship, such as the risk-taking personality (Frese and Gielnik 2014), start-up environment (Thornton 1999), business creation (Lazear 2005: 651-652), or how an opportunity is seized or taken advantage of (Shane and Venkataraman 2000).

This seems to indicate that it is difficult to get to grips with entrepreneurship from a cross-cultural and holistic perspective. For a start, this is because entrepreneurship is an ambiguous academic concept of agency that ranges from the philosophical notion of drivers of change to the mundane taxonomic assessment of business creation. The 'new entrepreneurialism' is also a larger socio-economic phenomenon of late modernity, where public-private partnerships and competition dominate public policy (Harvey 1989: 7). In addition, in the 'Age of Entrepreneurialism' (Comaroff and Comaroff 2009: 150), the entrepreneur is associated with utopias and dystopias of various kinds, ranging from the messianic archetype entrepreneurs from Silicon Valley to digital nomads, images of precarious self-employment, uncertainty and outsourcing as a consequence of global financial capitalism. As an ordinary category, entrepreneurship is often hard to translate, not only because the term is deeply rooted in a western mind-set of free will, choice and individualism.

In this contribution, I suggest (1) a classification of different research interests or approaches to entrepreneurship (2) present some of the classic works in anthropology exemplifying each of these categories and (3) discuss different empirical evidence from Spain to further illustrate the scope of each approach. I 
argue that critical approaches to entrepreneurship seek to undermine the moral framework underpinning entrepreneurship discourses and policies. This position may be included in a more general critique of neoliberalism where entrepreneurship is seen as a legitimizing device. A contribution from Mary Douglas on the entrepreneurial self illustrates this position, together with my analysis of the everyday social discourse on entrepreneurship in the context of the Spanish 2015 election campaigns. Contrary to this mainly academic position, the second section is going to talk about the affirmative approaches. These are typically linked to people and institutions committed to economic development policies. I make reference here to the works of Frederik Barth, Joseph Schumpeter and my own case study of a media entrepreneur in a rural area near Cordoba in 2009. In these cases, entrepreneurship is a question of how to understand bottomup-change seen as potentially positive. Thirdly, I talk about my research on heritage entrepreneurship and the Mediterranean diet in Spain. It is an example of an eclectic-pragmatic use of the concept in order to describe social phenomena as consequence of specific agencies. Irrespective of morally grounded reasons for 'supporting' or 'challenging' entrepreneurship, this approach takes the concept out of its characteristic spheres of employment, such as business creation, and capitalizes both on the agency-perspective and the eminence of that buzzword. In this line, the term is used in the notions of the social entrepreneur, the 'ethnopreneur' (Comaroff and Comaroff 2009) or the 'moral entrepreneur' (Becker 1963).

\section{Everyday politics of the entrepreneurial self}

Research on entrepreneurship has increased enormously over the recent twenty years, especially within the business school community (Carlsson et al. 2013: 919). Much of this literature is either euphoric (entrepreneurship is good), elitist (entrepreneurs are special), econometric (statistical-mathematical models account best for entrepreneurship) or narrow (entrepreneurship is an exclusive economic domain). These premises can be found in a recent work published in an influential business journal that maps the interdisciplinary domain of entrepreneurship research, with this definition of the field: 
Entrepreneurship refers primarily to an economic function that is carried out by individuals, entrepreneurs, acting independently or within organizations, to perceive and create new opportunities and to introduce their ideas into the market, under uncertainty, by making decisions about location, product design, resource use, institutions, and reward systems. The entrepreneurial activity and the entrepreneurial ventures are influenced by the socioeconomic environment and result ultimately in economic growth and human welfare (Carlsson et al. 2013: 914).

In the concluding remarks the authors celebrate the past Global Award for Entrepreneurship Research winners and defend a need to move from 'exploration' to 'explanation', from inductive-qualitative research to 'structural equation modelling and advanced econometrics' (Carlsson et al. 2013: 927). These arguments, more representative of conventional entrepreneurship research, produced different reactions in the social sciences in recent years. Increasingly, authors are concerned with a general critique of entrepreneurship (Armstrong 2005), its deconstruction (Nodoushani and Nodoushani 1999), unveiling its mythicizing and reification (Ogbor 2000). Others analyse the underlying discourse of entrepreneurship (Gill 2013), its narrative (O'Connor 2002), tales (Pitt 1998), prosaics (Steyaert 2004) and organizational storytelling (Boje and Smith 2010). Likewise anthropology, these linguistic analyses are interested in the ‘everydayness of entrepreneurship' (Steyaert 2004: 8).

The backbone of this unconventional research, I argue, is the identification of the ideological burden of entrepreneurship research, namely its methodological individualism. Some of the writings by Mary Douglas, including the article I discuss below, had an important influence beyond anthropology in the business world, setting the ground for this line of critique in the 1990s. In 1992, she wrote a thought-provoking essay on the political and moral construction of personhood and the self in what she called the enterprise culture. The enterprise culture is the 'doctrine of undiminished personal responsibility' where 'incompetence disqualifies' and 'the system tends to honour the person who organizes effective networks'. It promotes an unachievable ideal of the 'self-reliant, autonomous, responsible self' (Douglas 1992: 56, 60). 
This individualistic sociality is for Douglas opposed to other forms of social organization such as the hierarchical model (where the whole is transcending its parts) or the egalitarian enclave cultures (1992: 55-56). She holds that in the enterprise culture, the topic of personhood is taboo, since it is pushed towards a psychological lack of definition or vagueness that obscures the moral and political conditioning of the self (1992: 41,43). Together with the taboo protected metaphysical self, there is the rigid separated but complementary category of the person, which western religious, legal and economic institutions charge with exclusive responsibilities. As distinct cultural constructions of the self in past and present, such as the immortal soul of the Christians or the biological-determinist theories of gender differences, Douglas shows that these are always also political forms of coercion. In the following example, I show how this individualist social type Douglas describes is condensed in contemporary Spanish society in the figure of the entrepreneur. I outline how this archetype is both contested through everyday criticism in the context of economic hardship and vindicated as a way out of economic stagnation by ordinary people.

In 2015, there was a municipal, regional and national election year in Spain and the Andalusian capital Seville. In times of financial crisis, those in power claimed that the macro-economic data indicated recovery. The idea that the positive impact of austerity policies was beginning to be felt was one of their key messages. Meanwhile the opposition countered that ordinary people did not feel this recovery and that the general economic landscape continued to be frustrating. At the same time, socialist and conservative governments, from the local to the regional to the state, were blaming each other for fiscal austerity measures, corruption and, above all, unemployment. This was occurring in a context where data of 2014 from the Statistical Office of the European Union showed that Andalusia had a 61,5 per cent youth unemployment rate (ages 15 to 24) and constituted the region with the highest general unemployment rate $(38,4$ per cent) of all regions in Europe (Eurostat 2015).

In March 2015, the local economy section of a popular newspaper in the Andalusian capital Seville published an article with the title 'The entrepreneurs also feel the economic recovery' (Diario de Sevilla 2015). It showed the story of 
five start-ups in Seville driven by young entrepreneurs who did increasingly well in spite of the general economic depression. These kinds of success stories could be found in a similar vein across various media, but this particular article generated a heated debate in the online commentary section of the paper. On the one hand there were comments of those who defended the 'admirable courage' of people 'who don't only criticize but get things done'. On the other hand, the commentary of 'dédalo' exemplifies the critical lay voices (translations are mine):

As they open, they close. The market is saturated. There is no small business if there is no big business. We go direction of marroconized labour. Tetuán is full of entrepreneurs: sellers of slippers, species, musicians. In the end this is what we deserve. Let's sing the mea culpa or, if you can, emigrate.

In the following month, the electoral commission ordered the removal of a publicity campaign from the conservative municipal government in Seville. These widespread posters titled 'This is [let's say Pedro], a dreamer who became a creator with the aid of \#SevillaEmprendedora'. The leftist party Izquierda Unida had denounced successfully the campaign as allusive of institutional achievements and therefore as violating the Spanish election law. 'Sevilla Emprendedora' was a municipal institution promoting entrepreneurship created by the conservative party. A few days later, I read an advertisement from the socialist Andalusian government, encouraging 'collective entrepreneurship' through cooperatives.

Meanwhile, the entrepreneur and small businesses were also portrayed as the heroes of a hard-working civil-society painstakingly making their way up the economic ladder. In 2015, the recently created left-wing party Podemos was seen by some election polls as the strongest political force in the run-up to the parliamentary elections. Podemos attracted considerable international audience since Syriza, a declared sister-party, had already won the 2015 parliament elections in Greece fighting for what was perceived as a new politics of 'antiausterity' from the poor southern margins of Europe. The 'caste' a term made popular by Podemos leader Pablo Iglesias, which meant more or less the 'establishment', was placed in dialectical opposition to the 'majority' of ordinary people. These ordinary citizens were also small business owners, which appeared twice as a distinctive community in the first page of their political position paper 
(Podemos 2015). 'Small and medium-sized businesses' (PYMES) and self-employed (autónomos), were, together with exile-researchers, cooperatives and social movements, displayed as the explicit agency in opposing banks, military, taxevaders or U.S. rating-agencies.

Another example of this was the case of a young unknown autónoma from Cádiz, south of Seville. In February 2015, she posted a critique of the heavy tax-load for new start-ups in her personal blog. The headline that brought her post important media attention was 'How much does a freelance have to bill in order to earn 938 Euros in one month' (Gómez 2015; my translation). The answer in her case was 2, 000 Euros. The post was visited more than a million times and heavily quoted on both the internet networks and traditional media. This entrepreneur represented paradigmatically the young Spanish generation, often put as the 'most prepared ever' in public discourses which contrasted with the high youth unemployment figures in Spain. Academically trained, some opted for self-employment instead of emigration or unqualified and precarious labour. This is how she explained her attitudes in this popular post (translations are mine; my italics).

\footnotetext{
As the system does not create opportunities, two years ago, I decided that I was the one who was going to believe in myself, I took the risk and emprendí [which may mean both undertake something or start a business in Spanish]. [...] I believe in the entrepreneurial mentality but the system does not allow it. [...] in France in the first year [of business creation] you don't pay anything and you have the right to everything [social welfare provisions] and afterwards the taxes depend on your benefits. The same is true in the UK, where insurance costs range between 13 and 58 Euros.
}

In this lay theory, entrepreneurship is determined by the social context ('the system', state taxation) not by the individual genius ('mentality', self believe). The core theoretical assumption of the unitary responsible self as described by Douglas is challenged by this and other ordinary accounts and experiences of entrepreneurs in Andalusia in 2015. The 'individual-opportunity nexus', a theoretical framework popularized by Scott Shane (2003), the 2009 winner of the Global Award for Entrepreneurship Research, must have sounded cynical to the autónoma from Cádiz, the commentators at the Diario de Sevilla and the often young political activists at Izquierda Unida and Podemos. Thus, there is a dialectical 
tension between the official-institutional and the informal-ordinary notion of entrepreneurship in contemporary southern Spain.

In his classic work, Risk Society (1986), Ulrich Beck described Freisetzung or liberation as the process in modern societies that creates the very idea of agency or biography, which needs to be designed, reflected and constructed by individuals. This notion very much connects with Douglas' notion of the self in the enterprise culture. As the modern individual grows increasingly independent on traditional gender, kinship or religious obligations, Beck argued, dependency on more flexible institutions, such as the labour market, also grows. Maybe the indignation of the young entrepreneur from Cádiz had so much social resonance because Becks' modernization promise, already culturally assumed by this young generation, did not correspond with the social reality of Andalusia in 2015. Most young people from Cádiz depended more on the income of their extended families than on their own individual success in the labour market.

If, as Mary Douglas held, 'the culture that tends to give its members a sense of irredeemable guilt and inadequacy is the enterprise culture' (1992: 60), these examples from Andalusia show lay voices, everyday practices and new political movements of resistance to the political storytelling of the entrepreneurial self. What the critical approach to entrepreneurship then can show us is that the narrative of entrepreneurship has many lives and is transmuting into a site of conflicting ideologies and visions of the future.

\section{Mann der Tat: entrepreneurship in rural Andalusia}

The question of affirmative approaches is not how entrepreneurship works as discourse but what entrepreneurship is. If the critical approach tends to criticise the interested 'invention' of entrepreneurship, the starting point of affirmative approaches is the 'real existing' entrepreneur. In the following section, I discuss two classic works on entrepreneurship, by Joseph Schumpeter and Frederik Barth, which exemplify this affirmative line of research. Their work is building the grounds for the anthropologically coloured affirmative scholarship as they (1) use

a broad definition of entrepreneurs as 'drivers of change' favourable to 
interdisciplinary and holistic research and (2) empirically include a cross-cultural, comparative angle.

The 'businessman' has been a central concern for many of the founding fathers of social science such as Max Weber, Karl Polanyi or Karl Marx. Nevertheless, the Austrian economist Joseph Schumpeter is often credited with establishing the field of entrepreneurship research (Swedberg 2000: 12). Different to the standard 'founder of a business' definition, Schumpeter saw the introduction of novel, innovative forms of combining ideas and means of production in the economy as constitutive of the entrepreneur (1912: 174-75). It is the 'selection of ideas', the 'implementation of new combinations' of knowledge (not their invention, which would be part of science) that makes actions entrepreneurial (1912: 177).

His approach is compatible with cultural comparison in the sense that he conceptualizes the entrepreneur as a leader in the economic sphere, comparable with rulers in the political or commanders in the military sphere (1912: 177-78). Nevertheless, his concept is based on the twentieth century dichotomy between modern-dynamic-individualist and traditional-static-collective societies. Entrepreneurship, he argues, is likelier in the former rather than in the latter context, because in market driven societies the 'individual genius' is stimulated constantly by the credit-system (Schumpeter 1912: 162, 214). In opposition, in static-traditional, non-western societies, Schumpeter downplays the role of agency as the reason for economic change. Economic innovation here is the consequence of politics, religion or war (1912: 114), or the individual is simply irrelevant because of a general lack of role-differentiation between the economic and the political (1912: 179).

Schumpeters' heroic, masculine and western agency, the Mann der Tat, the man of action (1912: 182) combined with the entrepreneurship-as-innovation definition, is problematic when confronted with the anthropological claim for cultural relativism. Innovation, as well as development or modernization, are essentially moral and evolutionist categories, a way of looking at the future as potentially better than the present. Every moral community, constructed on ethnicity, age, religion, class or gender, has their own, quite heterogeneous standards of what this 
desirable future should look like. Maybe this is the reason why the classic anthropological work from Frederik Barth on entrepreneurship instead operated with the more open-ended term 'social change'.

In his plenary address to the American Anthropological Association in 1966, Barth summarized his general theory on entrepreneurship and social change (1967a). His selection of the anthropological niche topic of entrepreneurship allowed him to challenge the structural-functionalist school of thought, in decline during the 1960s and 70s, because it was increasingly accused of being ahistorical. Drawing on data from fieldwork in Sudan (1967b) and Norway (1963), Barth criticised an anthropological bias that favoured tradition not change, patterns not action.

\footnotetext{
Because of an interest in observing events of change, [we] decided to turn our attention to the study of entrepreneurs [...] The choice was rather obvious in that entrepreneurs are clearly agents of change: they make innovations that affect the community in which they are active (1967a : 663-664).
}

The example of Frederik Barth also fits with my classification of affirmative approaches to entrepreneurship, since his research in Sudan was related to funding, grants and assistance from institutions from the development industry, for instance, the Jebel Marra project of the UN special fund and the Ford Foundation. Since 1958 the UN

\footnotetext{
Special Fund was to be for 'pre-investment' types of projects aimed at creating conditions making new capital investment in a country either feasible or more effective [and] to concentrate on [...] development of manpower, industry, including handicrafts and cottage industries, agriculture, transport and communications, building and housing, health, education, statistics and public administration (UNESCO 2016).
}

Barth was interested 'not what makes the entrepreneur, but what does the entrepreneur make' (1967a: 664). Similar to his later work, where he advocated for a situational, relational, constructivist view on ethnicity (1969), his concept of entrepreneurship highlights choice, competition and strategy (1967a: 668) and employs agency-centred models of explanation, such as game theory (1967b). In his analysis of a Mountain Fur economic system in the Jebel Marra area in the Darfur region in western Sudan, based on a three-month field visit in 1964, he also 
privileges the view of 'single individuals' who look to satisfy their 'consumption profile' and some 'really attempt to maximize their assets' (1967b: 146, 155).

The entrepreneurial coup, where one makes one's big profits, is where one discovers a path by which something of little value can be transformed into something of great value [and] create new paths for the circulation of goods, often crossing barriers between formerly discrete spheres of circulation (1967a: 664).

Even when carefully considering the socio-cultural conditions of possibility of entrepreneurship, affirmative approaches can hardly do without the notion of an exceptional individual with a pass-breaking idea. Barth's account also includes the appealing character of the 'Arab merchant', an outsider who spent a rainy season in a village in the Jebel Marra asking for land to grow tomatoes. He was the first to take advantage of buying labour to produce cash crops: a profitable business. Barth suggests that the merchant was the first to bridge the sphere of the non-monetary labour market (where beer was the currency) and the monetary market for crops, thus

the beer-labour circle could be converted to the cash sphere by being used in the production of cash crops [resulting in an] advantage of the disparity in the beer versus the cash evaluations of labour. (1967b: 159)

Various lessons can be learnt from these works of Schumpeter and Barth in order to bring forward affirmative anthropological theorising on entrepreneurship. The pioneering universalistic and holistic scope of Schumpeter consists in the idea of entrepreneurs as a specific elite-typology that historically flourishes in a certain type of society, the western, but ultimately reflects a generic feature of social organization, the social hierarchy and the desire for upward-mobility. Barth shows how it is possible to register empirically what it is that makes certain actions, objects, services, ideas innovative in relation to a specific local social structure. The bridging of two economic spheres, monetary cash crop market and non-monetary labour market, is a specific local-temporal social context in the Darfur region of Sudan in the 1960s. He shows how innovation is articulated in (and potentially can be blocked by) mundane everyday-practices, such as 'buying' labour and selling goods. The institutionalization of this behaviour, through imitation, leads to social change. Taken together, both authors reconcile the individual with the social 
dimension of entrepreneurship, which has been held as a distinctive anthropological contribution to the field (Bjerregaard and Lauring 2012). In what comes next, I relate these theoretical insights to the case of a media entrepreneur from a rural region in central-southern Spain.

Los Pedroches is a region about $350 \mathrm{~km}$ south of Madrid. During the years of 2007 to 2010, I frequently visited this area for my $\mathrm{PhD}$ research. The following data draws on information from this fieldwork and statistics based on official database from the Andalusian administration (Multiterritorial Information System of Andalusia, SIMA). Los Pedroches was representative of larger parts of rural Spain, as it was marked by emigration, unemployment, an ageing population and subjected to different European, national and regional rural development programmes. The region had lost nearly half of its population since the 1960s. About 20 per cent of the jobs in the region were direct state employment (in areas such as health, administration and education), another 20 per cent of the jobs were concentrated in the agricultural sector, especially dairy and pig farming. The big employers also depended on subsidies, such as the regional milk cooperative, which in 2007 was the fifth biggest receiver of agricultural subsidies in Spain (Missé 2007).

Some of the vernacular theories of the unequal distribution of wealth in the region were related explicitly to a collectivistic notion of entrepreneurship. An informant told me that the people of Pozoblanco were more entrepreneurial because it was supposedly a Jewish settlement area. While others such as the 'Jarrotes', the name of the habitants of Villanueva de Córdoba were not considered especially entrepreneurial in the local opinion as the anthropologist Hernández León reported (2005: 217). Since the democratic opening of Spain in the late seventies, most municipalities in Los Pedroches had been governed by the socialist party, the same party that had governed the autonomous region of Andalusia uninterruptedly since 1978. The party was sometimes accused of having a corporatist and clientelistic relation with the poorer rural areas in Andalusia that depend heavily on the public employment schemes that were seen as the socialist party's core business. Since the 1990s, public rural development policies, inspired or directly driven by the LEADER programmes as part of the Common Agricultural 
Policy have fomented the ideas of entrepreneurship, bottom-up change and publicprivate partnership in Los Pedroches. The creation of publically funded jobs for the administration of entrepreneurship was among the various contradictory consequences of these policies. Five local and regional public development agencies committed to job creation and entrepreneurship existed in Los Pedroches.

Picking up the foregoing theoretical debate, one might ask: What does innovation, or more precisely, agency-driven impulses to social-change mean in this kind of region? Public-private partnerships or publically funded or guided private initiatives have a long history in the state-funded economy of Los Pedroches. Services on the periphery of the public administration or the commercial agricultural and construction sector, it could be argued, were fairly new to the socio-economic structure of the region. Some of these elements described reasonably well an initiative I studied in Los Pedroches in 2009. It was a private blogger, who wrote, nearly on a daily basis, sometimes critical-investigative, sometimes merely informative news articles. These covered a variety of topics, from arts to economic issues, from sport events to politics, from personal experiences as a citizen, to newspaper-like commentaries. The scope of these contributions was regional and the initiative became a well-known institution for the citizens of the region.

Why might this blogger be seen as an entrepreneur? The blog could be labelled as innovative in the context of Los Pedroches in various ways. It was the only medium (with exception of some short radio programs) dedicated exclusively to information and debates related to the region. It was, in principle, independent from political and economic interests or funding. This is to say that there was a clear non-institutional agency, a charismatic, academically trained, and financially independent individual with an extended social network in the region fitting with the driver-of-change definition. On the other hand, the blog was quite successful in social terms. At times, the platform had 300 daily visits, which was a number equivalent to 8 per cent of all households with internet connection in Los Pedroches. It was referenced throughout my fieldwork by different informants, for good or for bad, and appeared as a meaningful institution in everyday 
conversations. In an interview with a politician, I could see that he was actually just reading the blog and at times the information published in the blog was echoed in the super-regional newspapers.

One could argue that the local perception of the blog and its author were ambivalent. The commentary section of the blog was a battlefield for supporters and critics of both the content and its author. This entrepreneur and various commentators were publically known figures in this close-knit rural society. Nevertheless, various comments were made anonymously and touched on different taboos of the region, such as corruption or patronage in politics, business and everyday-life, including personal insults and family-wars. The blog thus introduced a discussion in the public space that was normally restricted to the private contexts of kin, friendship and locality. Consequently, the blog was an accelerator of public discourse and dispute in the region, sometimes uncovering information of public interest.

One of the main social movements I came across during my fieldwork was a citizen organization lobbying for a railway stop for the high-speed train from Seville to Madrid that passed through the region. Important economic outcomes for the region could be suspected from a new train station that had been opened finally in 2014 as a direct consequence of the pressure of this social movement, hence also of this media entrepreneur. The blogger accompanied all the activities of this group and gave them important media coverage within the region. He helped to mobilize protest actions that often where echoed in supra-regional media and forced local politicians to step outside of their party-guidelines. Simultaneously, the entrepreneur created a literary award for authors living in or born in Los Pedroches that attracted culturally interested citizens of the region. In this sense, the entrepreneur was a vital part of wider political, economic, cultural changes in Los Pedroches.

Nevertheless, this blogger did not fit the standard definitions of entrepreneurship. The blog neither was a business, nor was the initiative legally constituted in any other sense. There was no direct economic input or outcome. Creating and maintaining a blog, commenting on different topics related to your community 
might also not be seen as innovative from an elitist-western-urban point of view. The social, political and economic consequences of this media entrepreneur that participant observation can register, escaped a one-dimensional analysis of entrepreneurship. However, using Barth's terminology, this media entrepreneur was bridging formally discrete spheres, such as the public and the private, the local and the regional, state-party politics and social movements. He fitted Schumpeter's definition of a driver of change. It is in this direction, how an affirmative anthropological stance towards entrepreneurship contributes to widening our understanding of agency-driven change and the intimate interplay between social context and action, between economy, politics and civil society.

\section{Pragmatic neologisms and heritage entrepreneurship}

An eclectic or pragmatic approach to entrepreneurship does not care so much about what entrepreneurship actually is (as our previous discussion on the blogger), nor does it place criticism of a flawed concept at the centre of the analysis. Pragmatic approaches take the prominence of the concept as a given and look out for the possibilities that both the popularity and the methodological individualism of the concept offer for connecting scientific insight with everyday language. This position potentially runs the risk of a mere superficial-metaphorical employment of the term, characteristic for much of the contemporary media, corporate and political discourse on entrepreneurship. Nevertheless, I discuss the analytical potential of such a theoretical move in what follows.

Early signs of this kind of an eclectic approach can be found in Barth's edited book on entrepreneurship in Norway. In this volume, Eidheim describes the career of a Lappish politician as an enterprise or as political entrepreneurship $(1963: 70,81)$. That same year a concept coined by the American sociologist Howard Becker became popular. Becker held that 'moral entrepreneurs' were those who initiated the creation of rules, through the use of communication media and support institutions (1963: 122, 138-139, 147, 162). Becker's work is a good example to show how the agency-focused nature of the entrepreneurship concept is tactically used to reveal a hidden or downplayed agency-dimension of a given social 
phenomenon, in his case the entrepreneurial production of rules, deviance and outsiders.

Deviance is the product of enterprise in the largest sense; without the enterprise required to get rules made, the deviance which consists of breaking the rule could not exist [and the] enforcement of a rule is an enterprising act. Someone - an entrepreneur - must take the initiative in punishing the culprit (Becker 1963: 162, 122; my italics).

Becker is not interested in a critique or definition of entrepreneurship. In fact, in the chapter with this catchword as a headline, he is not concerned with exploring the concept at any time, because he is mainly discussing a concept he uses as analogous, the 'moral crusader'. Other prominent neologisms push this logic to its extremes in turning upside down the whole semantics of entrepreneurship, for instance 'social entrepreneurship', the employment of for-profit principles in notfor-profit organizations. Let me share a more extensive example that may give a clearer idea of what a pragmatic use of entrepreneurship in anthropological theorising could look like.

The second page of the contemporary classic Ethnicity, Inc. by John and Jean Comaroff (2009) starts with various quotes of a web presentation depicting Catalan identity by a North Catalonian website (a French region separated from the Spanish part of Catalonia). The Comaroffs suggest that Catalan identity is both commodified into a 'value added corporate collectivity' and 'claimed as the basis of shared emotion, shared lifestyle' (2009: 2). This example illustrates the common thread of the book, namely that ethnic communities increasingly take the form of corporations at the beginning of the twenty first century with the simultaneous commodification of their products and practices or, put in another way, the dialectic between the incorporation of identity and the commodification of difference (2009: 54, 138).

Ethnic or immigrant entrepreneurship has been for long an issue within mainstream entrepreneurship research, assuming that enclave communities have different problems, motivations and performance when starting businesses (Waldinger et al. 2000, Kloosterman and Rath 2003). The Comaroffs have instead coined the term 'ethno-preneurialism' with a quite different social phenomenon in mind. Ethno-preneurs capitalize on cultural objects and practices by commodifying 
their own identity. The authors describe this kind of sociality as profoundly ambiguous. On the one hand it is a tactical benefiting from one's own otherness (as the Catalonian example from the beginning), while on the other hand, in poorer parts of the world, the 'simulacra of ethnicized selfhood [is often] the only viable means of survival' (Comaroff and Comaroff 2009: 139). The worldwide phenomenon of ethno-preneurship has a violent and exclusivist dimension to it, as the competition over identity claims, authenticity and patrimony, often have a warlike character (Comaroff and Comaroff 2009: 144-145).

[Enthno-preneurs put] intellectual property regimes into work in the effort to secure the value vested in difference - and, in so doing, to render cultural identity into the language of copyright, sovereignty, and patent. [Ethon-preneurialism is] the management and marketing of cultural products and practices, qua intellectual property, as source of value - indeed, as a monopoly capital - inseparable from the being-and-bodies of their owner-producers (Comaroff and Comaroff 2009: 56, 51).

The ways in which the Camaroffs stretch the notion of entrepreneurship, I suggest, is representative of a pragmatic approach. As with other of their neologisms, such as law-fare (the use of legal means for political and economic ends) or policulturalism (plurality and its politization; see Comaroff and Comaroff 2009: 56, 52), the authors induce a creative intellectual tension that sparks speculation beyond the self-evidence of language. It is exactly this moment of estrangement, the combination of a powerful contemporary trope, such as entrepreneurship, with other traditional and apparently distinct fields of inquiry, such as ethnicity, law or heritage, which provides these accounts with its vitalizing inputs. The revelation of a hidden social phenomenon (the economics of identity) is combined here with the popularity of a buzzword. In addition, the pragmatic approach deliberately puts certain elements of the concept on its feet, for instance by defining the ethnopreneur as a collective subject, a 'me-as-we' (Comaroff and Comaroff 2009: 51, 141). Based on this pragmatic approach, I argued elsewhere (Pfeilstetter 2015), for the theoretical fruitfulness of the notion of heritage entrepreneurship in relation to an empirical case I develop briefly in the following.

The Mediterranean diet has recently been put on the UNESCO Representative List of Intangible Cultural Heritage of the World. The labelling of some aspects of culture as heritage traditionally has not been seen as subject to individual, private 
or corporatist initiative. Something is or is not heritage or worth safeguarding as a thing in itself. Its value apparently is objective, universal and not relative to agentive manipulation. Talking of heritage entrepreneurship is altering this focus as it stimulates to imagine heritage as a process, its conflictive and agency-driven constitution. De Bruin defines heritage entrepreneurship as the 'opportunities to acquire and/or safeguard customary, heritage-based resources' (2003: 170). This could be considered a broad definition because it does not say what heritage-based resources are. Heritage is the combination of objects, practices and ideas that are considered to have a special value or meaning for people. Heritage elements are symbols that represent specific, culturally distinctive communities. This is why the political or economic value of things, discourses, actions or people grows once these are convincingly associated with heritage. I suggest that this is exactly the value that is exploited by heritage entrepreneurs.

The Mediterranean Diet Foundation (MDF) was legally constituted as an NGO and created in 1996 on the initiative of an interest group of big food companies from Catalonia, an autonomous region in Spain. Both the MDF and these agribusinesses have their headquarters in Barcelona, the capital of Catalonia and had a series of sponsors and collaborators apart from these multinationals, from the political and the scientific sector. The MDF described itself as a cultural and scientific institution and had been coordinating the application of the Mediterranean diet as an element considered for the inscription on the mentioned UNESCO list. The application succeeded, and since 2013 the Mediterranean diet can be called Representative Intangible Cultural Heritage of the World. This 'UNESCO brand' is a resource and the MDF has taken advantage of the opportunity to acquire this resource, maintaining De Bruin's vocabulary.

Gastronomic heritage is an important value in Spain. Both the tourism and the food industry are among the basic pillars sustaining the Spanish economy. The Mediterranean climate gives rise to a specific touristic and agricultural product. Wine, olive oil, fruit and vegetable exports together with sun, beach and gourmet cuisine are all summarized in the label 'Mediterranean diet'. In the political arena, the Mediterranean is a space claimed from the central state as well as from Catalonian regional independence movements. For instance, at a ministerial 
meeting in 2015, Artur Mas, then the Catalonian president underlined Barcelona's 'vocation as a Mediterranean and European capital'. At the same meeting Mariano Rajoy, the Spanish president, called Barcelona 'the Spanish capital in the Mediterranean' (El País 2015). Both the Catalonian and the Spanish president used 'the Mediterranean' as a symbol that embodies their legitimate authority to represent the people from Barcelona. On the other hand current values, such as wellbeing, ecology or cultural diversity, linked to the Mediterranean diet through scientific research, is funded by business and politics. The MDF sells the sustainable, healthy and traditional character of the Mediterranean diet as scientifically proven (Mediterranean Diet Foundation 2015).

The stakeholders of the MDF were the Spanish and Catalonian governments, scientists from the socio-cultural as well as medical-nutritional fields and the Catalonian food industry. Among these was Prodeca, the promoter of Catalan exports or multinationals with headquarters in Barcelona, such as Danone. The MDF enabled all their stakeholders, through meetings, publicity, research, but primarily through managing and expanding the label 'UNESCO world heritage', to take advantage of the symbol Mediterranean diet. It created and sold an identity discourse, the Mediterranean culture, of great value in a country where national belonging was heavily disputed. The environmental-nutritional discourse allowed businesses to sell a more expensive touristic, gastronomic and agricultural product. The heritage discourse itself is an academic resource, as this paper shows.

Anthropological research has always identified key-players, leaders or emergent institutions that set agendas, cause conflict and change within the confined settings of a specific social structure. This is the case of the MDF within the Spanish socioeconomic context. I suggest that labelling this institution a heritage entrepreneur has a series of theoretical and practical rewards. It calls attention on the constructivist character of cultural heritage, it is a suitable metaphor to communicate our findings to broader audiences, and finally, by expanding the notion of entrepreneurship, it helps to point out the reductionism inherent in much of the more mainstream oriented definitions of the entrepreneur. 


\section{Conclusions}

We have seen how public political debates in Spain adopt the entrepreneur as a (de)legitimising symbol, from the political left to the right, from the government to the opposition, from the media to the common people. Local newspapers, popular blog posts, city councils' publicity or anti-austerity parties develop morally charged messages in Andalusia, based on the hero-image of the entrepreneur. I have shown how an affirmative approach to entrepreneurship can conceptualize bottom-up change in a holistic sense. Specific problems in rural southern Spain are addressed more accurately by some initiatives than by others. Finally, the case of the MDF reveals that entrepreneurship itself can and is used tactically by academia. The unusual labelling of an expert NGO that constructs and promotes cultural heritage as an 'entrepreneur' promotes research into the logics of agencydriven construction of cultural stereotypes.

Entrepreneurship has for long been of concern for anthropologists, but often more as a by-product when studying merchants, individualism or exchange (see for instance Goody 2004: 89). More recently, there is a growing interest of anthropologists to engage with entrepreneurship as a concept more explicitly (see Röschenthaler and Schulz 2015). The 'three-approach' classification of scholarship I have deployed here contributes to this emergent debate. My argument is explicitly not dialectical. The successive presentation of critical, affirmative and pragmatic entrepreneurship concepts should not be understood as thesisantithesis-synthesis, as I hold that different academic and professional positions can be equally suitable and legitimate. Not only because the selection of the empirical evidence and theoretical definitions of entrepreneurship differ, but also because they are often the consequence of divergent professional interests and mandates. In addition, by classifying my own research on entrepreneurship in Spain into these three categories, I look at the moving boundaries between my more enthusiastic PhD-related research, my critical stand as a lecturer in anthropology and the benefits that talking about entrepreneurship grants for research looking beyond the confines of academia. My three cases from Spain and the works from Douglas, Barth, Becker, Schumpeter and the Comaroffs I have discussed, give examples of different ways of approaching entrepreneurship in anthropology that may be equally suitable and legitimate but are different in scope 
and focus. I hope to contribute to a debate that, as I understand it, often asks the wrong question of whether or not to employ the concept, whether to criticise it or use it. Maybe it is more the question of 'how' that will ultimately allow us to develop more nuances in the anthropological research of entrepreneurship.

\section{References}

Armstrong, Peter 2005. Critique of Entrepreneurship. New York: Palgrave Macmillan.

Barth, Frederik 1963. The role of the entrepreneur in social change in Northern Norway. Bergen-Oslo: Norwegian Universities Press.

Barth, Frederik 1967a. On the Study of Social Change. American Anthropologist, 69, S. 661-669.

Barth, Frederik [1967b] 2000. Economic Spheres in Darfur. In: Swedberg, Richard. Entrepreneurship. The Social Science View. Oxford: Oxford University Press. S. 139-160.

Barth, Frederik 1969. Introduction. In: Barth, F. Ethnic Groups and Boundaries. London: George Allen and Unwin. S. 9-38.

Beck, Ulrich 1986. Risikogesellschaft. Auf dem Weg in eine andere Moderne. Frankfurt am Main: Suhrkamp.

Becker, Howard S. 1963. Outsiders: Studies in the Sociology of Deviance. New York: The Free Press.

Bjerregaard, Toke and Lauring, Jakob 2012. The socially-dynamic entrepreneurial process: an anthropological approach. International Journal of Entrepreneurial Venturing, 4 (2), S. 132-147.

Boje, David and Smith, Robert 2010. Re-storying and visualizing the changing entrepreneurial identities of Bill Gates and Richard Branson. Culture and Organization, 16(4), S. 307-331. 
Carlsson, Bo, Braunerhjelm, Pontus, McKelvey, Maureen, Olofsson, Christer, Persson, Lars and Ylinenpää, Håkan 2013. The evolving domain of entrepreneurship research. Small Business Economics, 41, S. 913-930.

Comaroff John L. and Comaroff, Jean 2009. Ethnicity, Inc. Chicago: University of Chicago Press.

De Bruin, Anne 2003. Indigenous entrepreneurship. In: De Bruin, Anne and Ann Dupuis. Entrepreneurship: New Perspectives in a Global Age. Burlington: Ashgate Publishing. S. 169-184

Diario de Sevilla 2015. Los emprendedores también notan el inicio de la recuperación económica, 3 March, at: <http://www.diariodesevilla.es/article/sevilla/1973740/los/emprendedore s/tambien/notan/inicio/la/recuperacion/economica.html > (accessed 5. March 2015).

Douglas, Mary 1992. The person in an enterprise culture. In: Hargreaves Heap, S. and Angus Ross. Understanding the enterprise culture. Edinburgh: Edinburgh University Press. S. 41-62.

El País 2015. Mariano Rajoy ensalza ante Artur Mas la españolidad de Barcelona, 13 April, at: <http://politica.elpais.com/politica/2015/04/13/actualidad/1428922826_5 70245.html > (accessed 15. April 2015).

Eurostat 2015. Database, 18 July, at:

<http://ec.europa.eu/eurostat/data/database> (accessed 18. July 2016).

Frese Michael and Gielnik, Michael 2014. The Psychology of Entrepreneurship. Annual Review of Organizational Psychology and Organizational Behavior 2014 (1), S. 413-38.

Gill, Rebecca 2013. The Evolution of Organizational Archetypes: From the American to the Entrepreneurial Dream. Communication Monographs, 80(3), S. 331-353. 
Gómez, Regla M. 2015. Cuánto tiene que ingresar un autónomo para ganar 938€ al mes, 20 February, at: <http://www.viviramimanera.com/cuanto-tiene-queingresar-un-autonomo-para-ganar-938e-al-mes/> (accessed 21. April 2015).

Goody, Jack 2004. Capitalism and modernity: the great debate. Cambridge: Polity Press.

Harvey, David 1989: From managerialism to entrepreneurialism: The transformation in urban governance in late capitalism. Geografiska Annaler, 71 B (1), S. 3-17.

Hernández León, Elodia 2005. Fronteras culturales: la construcción de los límites culturales en el Valle de Los Pedroches. Seville: Doctoral thesis.

Kloosterman, Robert and Rath, Jan 2003. Immigrant entrepreneurs: venturing abroad in the age of globalization. Oxford: Berg.

Lazear, Edward P. 2005. Entrepreneurship. Journal of Labor Economics, 23 (4), S. 649-680.

Lindh de Montoya, Monica 2000. Entrepreneurship and Culture: The Case of Freddy, the Strawberry Man. In: Swedberg, Richard. Entrepreneurship. The Social Science View. Oxford: Oxford University Press. S. 332-355.

Mediterranean Diet Foundation 2015. Internet presentation, at: <http://dietamediterranea.com/en/> (accessed 18. May 2015).

Missé, Andreu 2007. Las ayudas de la UE engordan las cuentas de grandes terratenientes. El País, 21. October.

Nodoushani, Omid and Nodoushani, Patricia A. 1999. A deconstructionist theory of Entrepreneurship. American Business Review, 17, S. 45-49.

O'Connor, Ellen 2002 Storied business: typology, intertextuality, and traffic in entrepreneurial narrative. The Journal of Business Communication, 29, S. 3654 . 
Ogbor, John 0. 2000 Mythicising and reification in entrepreneurial discourse: ideology—critique of entrepreneurial studies. Journal of Management Studies, 37, S. 605-635.

Pfeilstetter, Richard 2015. Heritage Entrepreneurship. Agency-driven promotion of the Mediterranean diet in Spain. International Journal of Heritage Studies, 21 (3), S. 215-231.

Pitt, Martyn 1998. A tale of two gladiators: reading entrepreneurs as texts. Organisation Studies, 19, S. 387-414.

Podemos. Documento final del programa colaborativo, at: <http://www.podemossevilla.info/articulos/documento-final-del-programacolaborativo/> (accessed 20. April 2015).

Röschenthaler, Ute and Schulz, Dorothea (eds) 2015. Cultural Entrepreneurship in Africa. New York: Routledge.

Schumpeter, Jospeh 1912. Theorie der wirtschaftlichen Entwicklung. Berlin: Duncker \& Humblot.

Shane, Scott 2003. A General Theory of Entrepreneurship: The IndividualOpportunity Nexus. Northampton, MA: Edward Elgar.

Shane, Scott and Venkataraman, Sankaran 2000. The Promise of Enterpreneurship as a Field of Research. The Academy of Management Review, 25 (1), S. 217226.

Steyaert, Chris 1998. A qualitative methodology for process studies of entrepreneurship, International Studies of Management and Organisation, 27, S. $13-33$.

Steyaert, Chris 2004. The prosaics of entrepreneurship. In: Hjorth, D. and C. Steyaert. Narrative and Discursive Approaches in Entrepreneurship Studies. Cheltenham: Edward Elgar. S. 8-21

Swedberg, Richard 2000. The Social Science View of Entrepreneurship: Introduction and Practical Applications. In: Swedberg, Richard. 
Entrepreneurship. The Social Science View. Oxford: Oxford University Press. S. 7-50.

Thornton, Patricia H. 1999. The Sociology of Entrepreneurship. Annual Review of Sociology, 25, S. 19-46.

UNESCO 2016. United Nations. Special Fund, at:

<http://atom.archives.unesco.org/united-nations-special-fund;isaar> (accessed 17. July 2016).

Waldinger, Roger, Aldrich, Howard and Ward, Robin 2000. Ethnic Entrepreneurs. In: Swedberg, Richard. Entrepreneurship. The Social Science View. Oxford: Oxford University Press. S. 356-388. 